\title{
Reducing the Livestock related green house gases emission
}

\author{
D Indira*, G Srividya \\ College of Veterinary Science, Proddatur, (A.P), India. \\ Veterinary Dispensary, I braheempatnam, Krishna district, AP, India \\ * Corresponding author email: indiradandolu@yahoo.co.in \\ Received: 13-09-2011, Accepted: 01-11-2011, Published Online: 18-12-2011 \\ doi: $10.5455 /$ vetworld.2012.244-247
}

\begin{abstract}
Cattle rearing generate more global warming green house gases than driving cars. These green house gases leads to changes in the climate. This climate change affects the livestock, man and natural environment continuously. For this reason it is important for livestock farmers to find the ways which minimize these gases emission. In this article the causes of climate change and effects, measures to be taken by farmers and their efficiency in reducing green house gases emission were reviewed briefly to make the farmers and students aware of the reduction of global warming green house gases and measures to be taken for reducing these gases.
\end{abstract}

Key words: Climate change, global warming, greenhouse gases, reduction of greenhouse gases, Livestock contribution to green house gases.

\section{To cite this article :}

Indira D and Srividya G (2012) Reducing the Livestock related green house gases emission, Vet. World. 5(4): 244-247, doi: 10.5455/vetworld.2012.244-247

\section{I ntroduction}

Livestock Production contributes to climate change when the green house gases methane, nitrous oxide and carbon dioxide are produced and released into the atmosphere. Ruminants are major culprits of the production of methane. It is therefore important for livestock farmers to try and find ways of reducing these emissions. Greenhouse gas emissions may be reduced by improving feeding practices, increasing productivity through breeding or by reducing livestock numbers. In order to identify what impact livestock has on climate change is known by its carbon foot print. A carbon foot print is defined as the total amount of greenhouse gases produced directly and indirectly from the Livestock is usually expressed in equivalent tones of carbon dioxide (Peterson and Rohrer 2010). Greenhouse gases (GHGs) are gaseous components of the atmosphere that absorb solar energy reflected from the earth's surface. This energy is transferred to the major non GHGs (nitrogen $(\mathrm{N})$ and Oxygen $\left(\mathrm{O}_{2}\right)$ resulting in an overall temperature increase in the lower atmosphere (De Klein et al. 2008). The main GHG emissions associated with livestock production are carbon dioxide $\left(\mathrm{CO}_{2}\right)$, Methane $\left(\mathrm{CH}_{4}\right)$ and nitrous oxide $\left(\mathrm{N}_{2} \mathrm{O}\right)$. Emissions from livestock are measured either in terms of $\mathrm{kg} \mathrm{CO}_{2}$ equivalent per $\mathrm{kg}$ meat or milk produced or per hectare of land used. Garnett (2007) identifies four main approaches to mitigatigating livestock green house gas impacts. These approaches focus on the areas of husbandry (Feed, genetics and lifespan), the management system, the number of livestock and managing the output (manure).

\section{Climate change causes and effects}

The climate change is considered to be a threat to the earth because of the effects that an increase of the earth's temperature. The earth's surface is heated by the visible radiation from the sun as well as by infrared radiation emitted by the atmosphere. The flow of energy from the atmosphere to the earth's surface is referred to as the "green house gas effect". There are gases in the atmosphere that absorb part of the radiation emitted back into space by the warmed earth and these are called green house gases (GHG). The greater proportions (about 96-99\%) of the gases (nitrogen $(\mathrm{N})$, oxygen $\left(\mathrm{O}_{2}\right)$, and argon $(\mathrm{Ar})$ that make up the atmosphere do not absorb or emit infrared radiation. The remaining constituents of the atmosphere are responsible for the greenhouse effect .These are primarily water vapour and carbon dioxide $\left(\mathrm{CO}_{2}\right)$ along with some other trace gases. These trace gases make up about $0.05 \%$ of the atmosphere however, they have a part to play in atmosphere pollution and also contribute to the green house effect 
(Dessler and Parson 2010).Of these trace gases, $\mathrm{CO}_{2}$ has the largest share and is the largest contributor to the green house effect after water vapour. The next largest is methane $\left(\mathrm{CH}_{4}\right)$ and it absorbs infrared some 20 times more than $\mathrm{CO}_{2}$ on a per molecular basis. Smaller greenhouse contributions come from nitrous oxide $\left(\mathrm{N}_{2} \mathrm{O}\right)$, chlorofluorocarbons $(\mathrm{CFC})$ and related synthetic chemicals and ozone $\left(\mathrm{O}_{3}\right)$. The earth's temperature continues to rise as the concentration of these gases continues to increase.

Livestock, man and the natural environment are continuously being affected by the effects of climate change. The changes in temperature may affect planting and breeding seasons, may cause stress in livestock and may trigger the emergence and spread of new and more aggressive pests and diseases. At the same time there may also be longer growing seasons and opportunities of growing wider range of crops. Changes in annual rainfall amounts and patterns, more frequent extreme weather conditions, rising sea level due to melting polar ice caps and changes in the ecosystem are other outcomes of climate change.

(Thornton and Gerber, 2010) observed that the livestock food chains are major contributors to greenhouse gas emission. (Steinfeld, 2006) also attributes a larger proportion of green house gas emissions in agriculture directly or indirectly to livestock production. He refers to the following as livestock related sources of green house gas emissions: enteric fermentation and respiration, animal manure, livestock related land use change, deforestation linked to livestock, livestock related release from cultivated soils, feed production, on farm fossil fuel use and post harvest emissions. (Garnett 2007) states that livestock reared in extensive systems, such as ruminants, tend to have a lower per area footprint than those in intensive systems like poultry and pigs, but have a higher footprint when expressed in terms of per $\mathrm{kg}$ of product. However livestock not only provide food, but have other contributions to the environment such as the role they play in maintaining ecosystem services and in the biodiversity of the land scape . Ruminants are also able to make use of plants that grow on non arable land and to consume agricultural byproducts that humans cannot make use of; meaning that they can utilize land that otherwise would not be suitable for food production (Garnett 2007, Pitesky et al 2009).

The amount of methane emissions differs in ruminants depending on factors such as animal species, breed, $\mathrm{PH}$ of rumen fluid, methanogen population, composition of diet and amount of concentrate fed. A significant amount of fermentation takes place in the rumen of ruminants that results in relatively large amounts of methane emissions per unit of feed energy consumed (Sejian et al. 2010).The amount of emissions also differs between developed and developing countries (Table 1). Cattle produce the most greenhouse gas emission among ruminants followed by sheep, goats and buffaloes.

Table-1: Average estimated methane emission rate through enteric fermentation for ruminants ( adapted from sejian et al 2010).

\begin{tabular}{llc}
\hline Animal Type & Region/Countries & Methane emission rate (g/animal/day) \\
\hline Cattle & Developed & 150.7 \\
& Developing & 95.9 \\
Sheep & Developed & 21.9 \\
& Developing & 13.7 \\
Buffalo & --- & 13.7 \\
Goat & --- & 13.7 \\
\hline
\end{tabular}

Measures to be taken by farmers and their efficiency in reducing GHG emission

The mitigation of greenhouse gases from livestock could be done by reducing emissions (efficient management of carbon and nitrogen flows in the livestock system), enhancing removals (carbon sequestration and building carbon sinks) or avoiding or displacing emission(crops and residues from the land are used as a source of fuel there by displacing emissions from fossile fuels) (IPCC 2007). Practices to reduce GHG emissions from livestock can be grouped as: improved feeding practices, use of specific agents or dietary additives, longer term management changes and animal breeding (Garnett 2007; IPCC 2007).

I mproved feeding practices: Methane emissions from livestock are mainly a result of enteric fermentation and eructation of methane represents a loss of energy to the animal (Gill et al. 2010). Mitigation options for enteric fermentation may either be aimed at an increased animal productivity such as increasing number of lambs produced or aimed at an increased animal productivity such as increasing number of lambs produced or aimed to effect rumen functioning like increased levels of starch or the use of additives. Garnett (2007) says that green house gases may be reduced by modifying the feed in such a way that the diet is adjusted to meet the nutritional needs more closely, by breeding new strains of grasses and cereals, improving pasture quality and by adding various nutritional supplements.

Feeding more concentrates: What the animal is fed will have a bearing on the amount of enteric and faecal methane emissions as well as the nitrous oxide emitted 
.when trying to reduce these greenhouse gas emissions through the adjustment of feed the main focus is on the balance between proteins, starch and fibre in the diet. This is because these have an influence on the levels of methane and nitrous oxide that will be produced. Methane emissions may be reduced by feeding more concentrate and reducing the intake of forage (IPCC 2007). This is because the fraction of feed converted to methane decreases when feed intake and feed quality increase (Garnett 2007). Feed conversion efficiency is improved when animals are fed concentrates and growth rate improves. They reach slaughter weight sooner resulting in fewer emissions.

With $\mathrm{N}_{2} \mathrm{O}$ the issue is not only about reducing the quantity of nitrogen that enters the system but about how efficiently the nitrogen inputs are converted into useful nitrogen outputs rather than being converted into urea and faeces. One way would be to optimize the protein intake to reduce the $\mathrm{N}$ excretion and nitrous oxide emissions. As changes are made to $\mathrm{N}_{2} \mathrm{O}$ emission from ruminants through the increase of starch or sugar content relative to protein, this will also have an effect on the reduction of methane emissions because the cause of emissions is inadequate digestion (Garnett 2007).

I mproving pasture quality: Forage quality may be improved by feeding forage that has lower fibre and higher soluble carbohydrates. Cellulose and hemicelluloses ferment more slowly than non structured carbohydrates thereby yielding more methane per unit of substrate digested (Eckard et al.2010). There are lower methane emissions when higher proportions of forage legumes are in the diet partly because of the lower fibre content, the faster rate of passage and also the presence of tannins (Eckard et al. 2010).Also, the nutrition that can be derived from legume forage is superior to that which can be found in grass only pastures due to the high protein content (Garnett 2007). Improving pasture quality, particularly in less developed regions improves animal productivity and reduces the methane emissions.

Nutritional and other supplements: One practice is the inclusion of oils and oil seeds to the diet (IPCC 2007). The addition of unsaturated fats such as coconut oil to the feed ration keeps the energy intensity of the diet high, reduces the need for grain based concentrates and also aids in the digestibility of fibre (Garnett 2007).

There are a number of additives that have been proposed for the reduction of methane emissions. These are ionophores, antibodies, halogenated compounds (condensed tannins, saponins or essential oils) and propionate precursors (fumarate and malate). Vaccines are being developed that contain an antigen derived from methanogenic bacteria and an immunogenic preparation that reduces the activity of rumen protozoa (Sejian et al. 2010).Bovine somatotropin (bST) and hormonal growth implants do not specifically suppress methane formation but improve the animals performance and thereby reduce emissions per $\mathrm{kg}$ of product (Garnett 2007; IPCC 2007).

Long term management and animal breeding: In dairy cows, increasing the productivity through breeding and the use of better management practices like reducing the number of replacement heifers often reduces methane out put per unit of product that is produced (IPCC 2007). According to (Eckard et al 2010) it was observed that there are variations between animals in the methane emissions per unit of feed intake and these variations suggest that there may be heritable differences in methanogenesis.

Reducing livestock numbers could be the best possible solution in countries where there are large livestock populations and who want to reduce their livestock related green house gas emissions (Sejian $e t$ al 2010). However this is not an option in countries where livestock plays a large role in the contribution of national income. If productivity increases through nutritional and breeding strategies, the number of livestock can be reduced without losing the quantity of meat that is currently produced (Garnett 2007). Another option would be to reduce the number of unproductive livestock. This may improve productivity as well as reduce emissions.

\section{Conclusion}

Several methods where indentified as measures for reducing greenhouse gas emissions in ruminants. These include improving feeding practices by increasing concentrates and reducing forage, improving pasture quality or the inclusion of nutritional and other supplements such as ionophores, antibodies and oil other management practices such as improving productivity through breeding and reducing livestock numbers may also reduce green house gas emissions. Better ration formulation to balance nutrients with real demand can result in more efficient use of nutrients and lower cost of production. Scientific development in feed formulation, improved animal genetics and changes in forage production could if promoted and encouraged continue to reduce the amount of GHG released. 


\section{References}

1. Deklein, C.A.M.., C.S.Pinares - Patino and G.C. waghorn (2008). Green house gas Emissions. Environmental impacts of pasture - based farming. R.Mc Dowell. Walling ford, UK Cambridge, MA, CABI: 1-32.

2. Dessler, A.E. and E.A. Parson (2010). The science and politics of global climate change: a guide to the debate . Cambridge university press.

3. Eckard, R.J.C.Grainger and C.A.M. Deklein (2010).Options for the abatement of methane and nitrous oxide from ruminant production. A review. livestock science 130(1-3): 47-56.

4. Garnett T. (2007). Meat and Dairy production and consumption: Exploring the livestock sector's contribution to the UK's green house gas emissions and assessing what less green house gas intensive systems of production and consumption might look like food climate research Network.

5. Gill, M., P. Smith and J.M.Wilkinson (2010). "Mitigating climate change: The role of domestic livestock" animal 4 (3):323-333.

6. IPCC (2007). Contribution of working group III to the fourth assessment report of the Intergovernmental panel on climate change, 2007. Cambridge united kingdom and New york, NY, USA, Cambridge university press.

7. Peterson, A.K.and J.Rohrer (2010). “What is a carbon foot print - definition. .Retrieved 17 September, 2010 from http://time for change .org / what -is -a carbon -footprint-definition.

8. Pitesky, M.E., K.R. Stackhouse and F.M. Mitloehner (2009). Chapter, clearing the Air. Livestock's contribution to climate change. Advances in Agronomy. D.L.Sparks. 103:1-40.

9. Sejian, V., R. Lal, J. Lakritz and T. Ezeji (2010). "Measurement and prediction of enteric methane emission". International Journal of Bio meteorology: $1-16$.

10. Steinfeld, H.,P. Gerber, T. Wassenaar, V. castel, M.Rosales and c.de hean (2006). "Livestock's long shadow: Environmental issues and options" Renewable resources journal 24(4): 15 .

11. Thornton, P.K. and P.J. Gerber (2010). "Climate change and the growth of the livestock sector in developing countries. "Mitigation and adaptation strategies for global change: 1-16. 